\title{
O que a saúde tem a ver com rádio comunitária? Uma análise de uma experiência em Nova Friburgo - RJ
}

\author{
What does health have to do with community radio? An analysis \\ of an experience in Nova Friburgo - State of Rio de Janeiro
}

Alfredo de Oliveira Neto ${ }^{1}$

Roseni Pinheiro ${ }^{1}$

\footnotetext{
${ }^{1}$ Departamento de Políticas, Planejamento e Administração em Saúde, Instituto de Medicina Social, Centro Biomédico, Universidade do Estado do Rio de Janeiro. São Francisco Xavier 524/7014, Maracanã. 20559-900 Rio de Janeiro RJ. oalfredoneto@gmail.com
}

\begin{abstract}
The field of Communication and Health in Brazil has been developing and getting stronger after each National Health Conference (NHC). In the final report of the XII NHC, in 2003, there was clear recognition that community radio is an instrument for the dissemination and treatment of issues related to the Brazilian Unified Health System (SUS). This study seeks to analyze the relationships that are established between health professionals, listeners/users and popular communicators as a means of understanding the nexus between a radio program on health and the imaginations of the listeners. A qualitative methodological approach was used of ethnographic and media audience methodologies. The field was a radio program about health, Bloco Mulher Saúde, broadcast by the Rádio Comunidade FM 104,9 in Nova Friburgo, State of Rio de Janeiro. The discussions were divided into analytical categories. The conclusion drawn is that community communication can be a cultural and political mediator for the expression of the demands of the community on health; the predominant medical jargon is maintained and reproduced by the physicians when participating on radio; community communication can contribute to the creation of strategies that broaden the social control of SUS.
\end{abstract}

Key words Health and communication, Community communication, Community radio. Democratization of the media, SUS
Resumo O campo da Comunicação e Saúde no Brasil vem se desenvolvendo e se fortalecendo a cada Conferência Nacional de Saúde (CNS). No relatório final da XII CNS, em 2003, torna-se claro o reconhecimento das rádios comunitárias como instrumento de divulgação e produção de temas relacionados ao SUS. O objetivo foi analisar as relações que se estabelecem entre profissionais de saúde, ouvintes/usuários e comunicadores envolvidos com uma rádio comunitária, de modo a entender como são constituídos os nexos entre um programa de rádio sobre saúde e os imaginários desses sujeitos. Para tal, uma abordagem metodológica qualitativa, fazendo-se uso da etnografia e do estudo de recepção. O campo se constituiu de um programa sobre saúde, o Bloco Mulher Saúde, transmitido pela rádio comunitária Rádio Comunidade FM 104,9 no município de Nova Friburgo, RJ. As discussões foram divididas em categorias analíticas. A comunicação comunitária pode contribuir como mediador políticocultural ampliando as possibilidades de expressão das demandas sobre saúde; existe a manutenção e reprodução do linguajar técnico hegemônico em saúde pelos médicos ao participarem de uma rádio comunitária; a comunicação comunitária pode auxiliar na construção de estratégias para ampliar o controle social no SUS.

Palavras-chave Comunicação e saúde, Comunicação comunitária, Rádio comunitária, Democratização da mídia, SUS 


\section{Introdução}

\section{Ondas populares}

O conjunto de mídias (rádio, TV, jornal, internet), produzido por sujeitos organizados em algum espaço coletivo (associação, igreja, clube etc), e destinado à população do mesmo território, é denominado comunicação comunitária. $\mathrm{O}$ movimento popular e político para produção e circulação desses canais alternativos de comunicação não possui suas raízes no presente.

De acordo com $\operatorname{Cogo}^{1}$ e Fernandéz ${ }^{2}$, a comunicação comunitária se estabeleceu no Brasil graças a setores progressistas da Igreja Católica, reunidos principalmente em torno das Comunidades Eclesiais de Base (CEB), e graças a projetos na área da educação e cultura nos anos pré-ditadura militar de 64, influenciados pelos pensamentos de Paulo Freire, como o Movimento de Educação de Base (MEB) e o Movimento de Cultura Popular (MCP).

Durante o período de ditadura militar (19641985), muitas mídias foram vítimas de censuras e fechamentos. Segundo Costa $^{3}$ poucos grupos se beneficiaram de tal período, tendo-se como exemplo mais significativo a Rede Globo, cuja TV surge em 1965, através de um convênio com a empresa norte-americana Time-Life, sendo beneficiada politicamente pelo governo militar brasileiro.

No início da década de 80, apesar desse cenário, foi formada a Frente Nacional de Lutas por Políticas Democráticas de Comunicação (FNPDC), composta por partidos políticos, estudantes e jornalistas no intuito de acumular e amadurecer o debate, visando atingir uma discussão madura no momento da Constituição de 1988. Segundo Cassol ${ }^{4}$, o surgimento da FNPDC tem como estopim as suspeitas de manipulação midiática do movimento Diretas Já, porém assume a institucionalização de lutas a favor da democratização da comunicação com raízes ainda na década de 60 já descritas anteriormente.

Após a Constituição de 1988, a FNPDC se desarticula, voltando ao cenário em 1991 por iniciativa da Federação Nacional dos Jornalistas (Fenaj) com o nome de Fórum Nacional pela Democratização da Comunicação (FNDC), que se torna entidade apenas em 1995. Desde então a FNDC vem funcionando e ocupa espaços no Conselho de Comunicação Social e no Comitê Consultivo do Sistema Brasileiro de TV Digital.

Voltando ao cenário da redemocratização brasileira, de acordo com Leal ${ }^{5}$, em 1984 o Brasil já contava com 40 emissoras de rádios livres com caráter eminentemente político: envolvido diretamente com as Diretas Já, ou com movimentos de democratização da mídia. Apesar desses esforços, na Constituição de 88 não houve a inclusão de rádios comunitárias no sistema nacional de comunicação.

Importante deixar claro a diferença entre rádio livre, sem a liberação oficial para funcionar, conhecida também pejorativamente como "pirata”, e rádio comunitária, que muito recentemente possui o potencial de se conseguir a legalidade, porém com características de limitação técnica e de sustentabilidade como veremos adiante.

Em 1993, é formada a Associação Brasileira de Radiodifusão Comunitária (Abraço), composta por movimentos sociais, incluindo-se a FNDC. Uma das primeiras pautas desse movimento é a tentativa de pressionar o poder Legislativo para que haja a elaboração de uma lei específica para as rádios comunitárias, o que acontece após muitos entraves com a Associação Brasileira de Emissores de Rádio e Televisão (ABERT), formada pelas empresas comerciais de radiodifusão e liderada pela Rede Globo. Finalmente, em 1998 é sancionada a Lei de Rádio Comunitária (Lei 9.612/98) ${ }^{6}$.

Em contrapartida, as exigências técnicas de funcionamento pautadas pela lei são bastante limitantes, pois permitem a veiculação da transmissão com uma potência de $25 \mathrm{w}$, uma antena de no máximo 30 metros de comprimento e uma abrangência de cobertura de $1 \mathrm{Km}$ de raio, o que limita, e muito, rádios que se localizam na área rural por exemplo.

Além da exigência técnica, há outros impasses: restrição de uma única emissora em cada bairro/vila; proibição de fins lucrativos, mesmo que seja para manutenção da rádio através da proibição de publicidade comercial.

Nota-se, pois, uma nítida proposta de se restringir economicamente as atividades da rádio comunitária em favorecimento das rádios comerciais. A própria Lei de Rádio Comunitária, segundo $\mathrm{Leal}^{5}$, apesar do reconhecimento das rádios comunitárias pelo Estado, parece atuar de forma contrária aos interesses dos comunicadores comunitários, tendo inclusive um papel de dissipação das lutas coletivas a favor da democratização da comunicação que vinham tomando força durante o período de redemocratização do País.

No entanto, apesar dessas restrições, a quantidade de rádios comunitárias no país, conforme Görgem et al. ${ }^{7}$, não para de crescer: até 2008 havia no país 9472 veículos de comunicação em 
atividade, desses, 2408 são rádios comunitárias, 1012 jornais e 421 emissoras de televisão.

Em 2007, segundo Leal ${ }^{5}, 1364$ processos estavam em tramitação no Ministério das Comunicações (Minicom) e 4555 pedidos de concessão de rádios comunitárias estavam arquivados. Isso sem contar com as inúmeras rádios livres que não entram nos números oficiais.

Em contrapartida, as repressões e perseguições da Polícia Federal às rádios comunitárias não cessaram e, em algumas regiões, segundo Paiva ${ }^{8}$, aumentaram, apesar da legislação vigente e do relativo aumento no número de concessões e de licenças provisórias cedidas pelo Minicom.

Apesar de um cenário jurídico e politicamente desfavorável para a comunicação comunitária, pequenos grupos vêm se esforçando para ampliar os espaços comunicativos via rádios e televisões comunitárias, TV pública e internet.

Diante desse cenário, de que maneira esse universo da comunicação comunitária dialoga com questões relacionadas à saúde?

\section{O que a saúde tem a ver com comunicação comunitária?}

A questão do reconhecimento da necessidade de se discutir comunicação no âmbito da saúde é de certa maneira recente. Na saúde coletiva, essa necessidade vem se tornando crescente a partir do nascimento do SUS, o qual possui nas suas raízes, através da VIII Conferência Nacional de Saúde, o direito à informação, e em suas diretrizes a participação social na fiscalização de serviços e formulação de políticas públicas.

O campo da Comunicação e Saúde (C\&S) surge a partir desse cenário de construção do SUS e se fortalece à medida que as Conferências Nacionais de Saúde (CNS) vão se solidificando na agenda dos movimentos sociais ${ }^{9-11}$.

Para Araújo e Cardoso ${ }^{12}$, a comunicação na saúde no País tem seguido um caminho inverso ao processo de descentralização pautada pelo SUS. De acordo com as autoras, a concentração de falas autorizadas e hegemônicas acaba sendo aprimorada mesmo em iniciativas que supostamente têm como objetivo a facilitação do acesso da população às informações em saúde. Daí a pergunta: onde estão as vozes da participação? Segundo as autoras: "São escassos os processos que se destinam a identificar quem são e onde estão as outras vozes e oferecer mais e melhores condições de produção para o que elas têm a dizer"12.

Nessa mesma linha de raciocínio, para que se haja um controle social efetivo dos serviços, po- líticas e práticas na saúde, há de se permitir uma maior participação dos usuários para que se possa escutar e tentar compreender suas questões, dúvidas, reclamações etc.

Partimos do pressuposto de que, para se continuar obtendo conquistas em relação ao SUS, é necessário ampliar e qualificar a escuta das demandas de saúde dos sujeitos. E a comunicação comunitária entra como uma ferramenta interessante no sentido de propiciar um aumento na possibilidade de expressão da demanda num espaço que não é a de um consultório médico, e nem a de um gabinete de um gestor, mas num espaço inserido dentro da comunidade dos usuários de saúde, onde as relações entre estes estão fortalecidas, um espaço representante da cultura local e potencialmente democrático.

\section{Metodologia}

Utilizamos uma abordagem metodológica qualitativa, fazendo-se uso da etnografia dentro do contexto teórico do estudo de recepção.

\section{Estudo de recepção}

Caracteriza-se como uma aposta de transformação do antigo modelo de se pesquisar o impacto da mensagem, baseado segundo o paradigma informacional norte-americano e britânico da primeira metade do século XX. Tal modelo, proveniente da escola funcionalista ou mass communication research, pautava-se na avaliação do impacto da comunicação na cultura de massas produzida pela vertiginosa indústria cultural da época. Eram estudos que focavam o emissor e os meios de comunicação e, quando se estudava o receptor, se fazia através de metodologias quantitativas privilegiando as pesquisas de mercado, tendo-se como ponto de análise o sujeito como consumidor ${ }^{13-14}$.

O foco das investigações no estudo de recepção se baseia no impacto dos meios de comunicação no sujeito através da pesquisa crítica da audiência, "e não a pesquisa meramente funcional da audiência para os objetivos de uma produção"13. São autores que se dedicaram a investigar o sujeito-receptor através de metodologia qualitativa.

Os estudos de recepção foram ressignificados à luz da realidade da América Latina em meados da década de 80 principalmente por Jesús Martín-Barbero, Nestor García Canclini e Guilherme Orozco. Esses autores, analisando o espaço cul- 
tural, onde o sujeito está inserido, revelaram que o foco principal nas pesquisas de comunicação deve estar no sujeito e como ele negocia, resiste e produz sentidos em relação aos interesses e propósitos do emissor através da mensagem que está sendo veiculada naquele momento ${ }^{13-15}$.

Nesse sentido, o presente trabalho utiliza os estudos de recepção à medida em que tem como objetivo a interpretação da análise dos sujeitosreceptores diante dos trechos de áudio selecionados do programa de rádio.

Foram selecionados 5 programas do Bloco Mulher Saúde, programa semanal de 1 h de duração da rádio comunitária Rádio Comunidade 104.9 FM de Nova Friburgo (RJ). O critério de prioridade de eleição dos trechos se deu a partir da possibilidade de se prestigiar atores diferentes no campo da saúde numa rádio comunitária: o ouvinte, o político, o médico e o radialista. Durante o período de investigação etnográfica esses atores compuseram a matéria-prima para os debates no Bloco Mulher Saúde. Cada um dos atores abordaram temáticas diferentes: rádio comunitária, atenção primária, prevenção de doenças e medicalização.

Foram selecionados 4 trechos, priorizando as seguintes temáticas e falas:

1) Ouvinte da rádio: o papel da rádio em servir como escoamento das demandas de saúde local;

2) Político: a situação da atenção primária em Nova Friburgo;

3) Médico: destacando o caráter de prevenção de uma determinada doença;

4) Radialista: um produto pré-gravado de comunicação em rádio chamado spot, apresentando uma temática de educação em saúde, no caso, a questão do excesso de medicalização na infância.

Importante frisar que o projeto inicial, de se aplicar o estudo de recepção com os usuários de saúde nas salas de espera das Unidades de Saúde de Família, foi impedido pela secretaria de saúde de Nova Friburgo sem justificativas plausíveis. Um gestor chegou a questionar “(...) não tem uma outra rádio para você pesquisar aqui em Friburgo? Tem que ser essa?"11.

Os 4 trechos selecionados foram exibidos a 3 ouvintes da rádio e a 1 trabalhador de saúde da atenção primária em Friburgo. Foram construídas 6 perguntas norteadoras:

1) Você ouve esta rádio?

2) O que você entende desse trecho?

3) Qual o sentimento que você teve diante da notícia?
4) Você percebe essa notícia acessível para o morador de Friburgo?

5) Você acha que essa notícia poderia lhe ajudar no seu dia-a-dia?

6) Você acha que é papel de rádio comunitária servir como instrumento de promoção à saúde?

\section{Pesquisa etnográfica}

Utilizamos 3 técnicas de investigação.

a) Observação participante: foram no total 8 visitas realizadas entre abril e julho de 2009. Havia dois momentos: um para o programa Bloco Mulher Saúde, com duração de $1 \mathrm{~h}$, ao vivo nas manhãs de quinta-feira, no estúdio da Rádio Comunidade 104.9 FM em Nova Friburgo (RJ); o outro para pesquisa de documentos e entrevistas. Essa observação resultou em um diário de campo;

b) Entrevistas: foram entrevistados 10 atores sociais ( 2 conselheiros municipal de saúde, 2 ouvintes, 2 radialistas, 2 profissional de saúde, 2 atores envolvidos no início da emissora). As entrevistas foram abertas e em profundidade, com duração média de $1 \mathrm{~h}$, precedidas de contatos via telefone e e-mail, devidamente consentidas pelos atores, que assinaram o termo de consentimento livre e esclarecido. Foram realizadas em várias localidades: emissora Rádio Comunidade, Conselho Municipal de Saúde de Friburgo, USF e locais diversos de trabalho e residência dos entrevistados;

c) Análise de documentos: ata de fundação da rádio, atas de reuniões do conselho gestor da rádio, matérias de jornais locais e do Rio de Janeiro e relatórios de Conferências Municipais de Saúde em Nova Friburgo.

A partir da análise do material empírico coletado, elegeu-se, baseados em Minayo ${ }^{16}$, três categorias empíricas, as quais, emanadas da realidade, parecem dialogar de uma maneira mais aproximada com o objeto em questão:

a) O papel da comunicação comunitária nas práticas de controle social e nos cotidianos dos serviços de saúde;

b) Medicalização e conhecimento popular: o linguajar técnico em saúde na comunicação comunitária;

c) Comunidade e comunicação na saúde: desafios na construção de estratégias de participação. 


\section{Resultados e discussões}

\section{O papel da comunicação comunitária nas práticas de controle social e nos cotidianos dos serviços de saúde}

Através das análises dos dados, observou-se que um dos usos da Rádio Comunidade - como mediador político, cultural e social - durante o período estudado foi contribuir com o Conselho Municipal de Saúde de Nova Friburgo, facilitando o controle social na saúde. A seguir um caso em que, pela análise dos entrevistados, a articulação da rádio com a sociedade civil foi decisiva para garantir a $6^{\mathrm{a}}$ - Conferência Municipal de Saúde (CMS) de Nova Friburgo em 2008.

Uma radialista da Rádio Comunidade relata: As rádios comunitárias falam das deficiências da gestão pública, é um grande espaço de controle social. Por exemplo, ano passado [2008], a $6^{a_{-}}$CMS não iria acontecer. A Secretaria de Saúde ligou para rádio para dizer que a CMS não iria acontecer. [...] Alegaram que não poderia acontecer, pois não tinham sido articuladas as pré-conferências, $e$ todo mundo sabe que as pré-conferências não são pré-requisitos para acontecer uma CMS, apenas ajudam o processo. [...] O Conselho Estadual da Saúde (CES) já sabia da decisão da Secretaria. Aí, começou a mobilização na rádio, consegui ligar para várias pessoas do Conselho [Conselho Municipal de Saúde de Friburgo], CES e do Ministério da Saúde [MS]. Isso foi numa tarde... Na outra manhã, estavam uma pessoa do MS e outra do CES no ar ao vivo para falar desse assunto... Depois disso, a Secretaria ligou novamente dizendo que o CMS iria acontecer. [...] A ex-secretária, que é a atual vereadora Neusa [nome fictício] dizia pra todo mundo: "como não vou fazer isso [liberar a CMS] com a rádio [Rádio Comunidade FM] e a TVC [TV Comunitária de Friburgo] no meu pé o dia inteiro..." (Radialista1).

Um conselheiro de saúde, também entrevistado, analisa o caso do cumprimento da $6^{\mathrm{a}}$ - CMS como ator social do processo e ratifica, assim como o relato acima, a importância da Rádio Comunidade como órgão de pressão comunitária, favorecendo os interesses públicos.

A Rádio Comunidade teve uma participação importantíssima, foi um dos primeiros órgãos de comunicação a tomar conhecimento. [...] Dali em 2 horas não se falava mais em outra coisa. A Maria [nome fictício] foi muito prestativa, foi um canal de comunicação realmente direcionada ao interesse público, porque não envolvia dinheiro, não envolvia propaganda, não envolvia comercial. Nós vemos exatamente aí a força da Rádio (Conselheiro de saúde 1).

Esses relatos evidenciam o potencial que uma rádio comunitária pode exercer contra o autoritarismo político vigente em muitas regiões do país, garantindo a existência de um espaço democrático para justamente fiscalizar, formular e executar políticas públicas de saúde locais. Um ouvinte da Rádio Comunidade, expressa esse potencial exercido pela rádio: "o papel da rádio como interlocutora da sociedade, onde passa a ser uma trincheira, onde a sociedade tem voz para poder denunciar, fazer suas reclamações, fazer suas exclamações das suas necessidades." (Ouvinte 1).

Em outra situação, o poder local de fiscalização das ações do governo municipal que algumas mídias (rádios e TVs comunitárias) assumem, segundo uma profissional de saúde da Atenção Primária, é extremamente presente também nos serviços de saúde. Para ela, esse receio em relação à exposição midiática produzida pela mídia local contribui para uma mudança instantânea na dinâmica dos serviços, como se a gestão local de saúde estivesse produzindo esforços para mostrar um cenário que não correspondesse à realidade.

Essa TVC [TV Comunitária Friburgo] vai para os postos, para as filas, aí o pessoal [da secretaria de saúde] fica doido, liga e diz "tenta abrir mais números [de consulta]" e eu digo "como? Só tem 1 médico, 1 enfermeira”... Eles ligam, "fiquei sabendo que a TVC está passando nos postos". Aí é aquela correria. Por exemplo, o Conselho [Conselho Municipal de Saúde] também quando passa, normalmente, a coordenação [de Saúde da Família] é avisada (Profissional de saúde 2).

Esta mesma trabalhadora denuncia um fato de extrema gravidade que numa ocasião já lhe ocorreu. Devido a rumores de que a TV Globo estaria chegando ao serviço para realizar uma reportagem, ela relata como foi o posicionamento e orientação dos seus superiores sobre o destino de medicamentos vencidos no estoque da farmácia do posto de saúde.

[...] já recebi orientação em relação a medicamento vencido. "Medicamento vencido, o que faço?", aí dizem "quebra, joga no vaso, porque se a Globo chegar já viu, né?”. São orientações de quem não deveria me orientar desse jeito. [e não era para fazer isso, né?]. Não, era para devolver para a farmácia e ela incinerar, são produtos químicos, então como vou jogar no vaso um monte de antibióticos? (Profissional de saúde 2).

Esses exemplos atestam a importância e o impacto da hegemonia de algumas mídias no 
cotidiano dos serviços públicos de saúde. No entanto, nesses casos, a aproximação entre a mídia e os serviços de saúde acabou gerando consequências negativas e irresponsáveis.

Em relação à transparência no SUS em Nova Friburgo, um conselheiro de saúde aposta no papel de ouvidoria que as rádios comunitárias poderiam estar exercendo no cotidiano dos serviços.

As rádios comerciais se utilizam da desgraça do povo, do mau gerenciamento do gestor público para se enriquecer. Quanto mais desgraça, mais assunto eles têm. Se a rádio comunitária tivesse um programa específico sobre saúde, educação, estrutura da cidade, ela seria ouvida o tempo todo. Porque a população estaria antenada o tempo todo. O que é que houve naquele hospital, o que é que houve naquela clinica? E aí o povo teria um canal para reclamar.

Dentro dos hospitais se tem a ouvidoria, mas num hospital que atende cerca de mil pessoas por dia um ouvidor não resolve o problema. "A rádio comunitária faria o papel de ouvidor do povo" (Conselheiro de saúde 1).

Embora não tenhamos encontrado estudos que descrevam esse caráter de ouvidoria das questões de saúde relacionado à rádio comunitária, o contrário, ou seja, a importância das informações sobre saúde no sentido (rádio > usuário) é descrita no relatório do Fundo das Nações Unidas para a Infância (UNICEF) em 2008, o qual menciona "muitas rádios comunitárias, em antítese às campanhas detratoras difundidas por rádios comerciais, têm auxiliado os serviços de saúde a levarem informações importantes para a população" ${ }^{17}$.

No primeiro caso relatado, envolvendo a Rádio Comunidade FM e o Conselho Municipal de Saúde, a conquista de espaços de coletividade para se discutir a saúde local amplia as possibilidades para uma melhor interação entre comunicação comunitária e serviços de saúde.

\section{Medicalização e conhecimento popular: o linguajar técnico em saúde na comunicação comunitária}

Um dos aspectos encontrados na análise dos dados remete a um problema que aflige grande parte das rádios comunitárias: a reprodução de falas hegemônicas oficializadas, utilizando-se muitas vezes uma linguagem rebuscada de difícil acesso a uma parte dos ouvintes ${ }^{8,18,19}$.

$\mathrm{Na}$ audição dos trechos dos programas, realizada com um idoso numa praça da cidade de Nova Friburgo, exatamente no trecho em que um médico mastologista, entrevistado do programa da rádio, explica como se origina o câncer de mama e como se previne, Severino [nome fictício] automaticamente remete ao seu conhecimento popular sobre o assunto.

Enquanto o entrevistado [médico] falava de expressões como risco relativo, gene BRAC $1, B R A C$ 2, heredograma, mastectomia, estrogênio, isoflavona, fitoestrógenos, Seu Severino [nome fictício] comentava: "sabia que uma mulher com câncer de mama pode passar para outra?" Aí contou o caso de uma vizinha que acabou "passando" seu câncer para outra (Diário de campo).

A interpretação popular sobre os fatos do cotidiano, mesmo sendo incompatível com as normas e as leis da ciência, pode ser abordada por uma mídia comunitária sem se perder o senso crítico e o poder de resposta sobre o assunto. Grande parte do conhecimento popular no que diz respeito à interpretação do processo saúdedoença e ao tratamento de doenças através de rezadeiras, manipulação das plantas etc. é amplamente marginalizado pelo espaço hegemônico da imprensa que privilegia o discurso científico oficial.

Uma das questões importantes relacionadas à comunicação comunitária, portanto, é a garantia de um discurso midiático plural, que permita a existência de posicionamentos de diferentes matizes ideológicas. $\mathrm{O}$ fato de existir a fala de um especialista numa rádio comunitária não garante necessariamente uma informação com qualidade, não só no seu conteúdo, mas principalmente na função educativa em compreender e ser compreendido.

Um dos entrevistados assume o posicionamento de que deve existir a democratização do saber por parte do profissional de saúde quando no lugar de uma mídia comunitária.

O profissional acha que tem que deter o poder e não acha que tem que passar aquele conhecimento que ele tem para a população. A rádio comunitária deve ter esse papel de chamar o profissional de saúde para dar esclarecimentos. Não só da saúde, mas também da educação e de outras áreas, porque tudo isso está interligado. Não há saúde sem educação (Conselheiro de saúde2).

Um dos trechos de áudio selecionados tinha como conteúdo um spot (um fonograma utilizado como peça publicitária em rádio) sobre os abusos da medicalização na infância. Esse spot enfatiza os perigos em relação ao uso indiscriminado de antitussígenos, antitérmicos e analgésicos.

Uma profissional de saúde, após audição do trecho, declara a dificuldade de se conduzir um 
tratamento não-medicamentoso, principalmente quando se precisa negociar isso com a mãe de uma criança enferma.

Então lá [no outro posto] eu dava essas orientações de muito líquido, alimentação e no final a mãe perguntava: "e não vai passar um xarope não?” Então tem essa necessidade de sair com um remédio [...] Se você não der remédio, eles na próxima vez, não vão querer ser atendidos pela enfermeira, "ah, não tem um médico aí não?", "enfermeira não passa nada". E lá tinha uma pediatra que eles adoravam, porque [risos] era uma médica que eu nunca vi passar tanto remédio quanto ela. As mães saíam com sacolas, tinha mãe que toda semana estava lá (Profissional de saúde 2).

Nesse caso, as mídias comunitárias podem contribuir com conteúdos que problematizem a questão da medicalização, no intuito de favorecerem a autonomia do sujeito perante seu processo de saúde-doença. No caso do spot em questão veiculado pela Rádio Comunidade, a profissional de saúde acredita que conteúdos radiofônicos como esse poderiam estar auxiliando no seu cotidiano na APS se veiculados, por exemplo, numa sala de espera de uma USF: "no dia em que eu falasse assim: 'não, mãezinha, você não vai levar xarope, você vai fazer isso, isso e aquilo', acho que ela iria acreditar mais." (Profissional de saúde 2).

O que está posto aqui não é a garantia de mudança de práticas do usuário justificada apenas pelo contato com conteúdos veiculados em mídias comunitárias, porém que tal mídia funcione como um coadjuvante nas práticas de educação e saúde.

A questão do "acreditar" da "mãezinha" passa não só pela confiabilidade no discurso biomédico, mas principalmente pelo contexto sociocultural em que se está inserido.

Tesser $^{20}$ analisa a dificuldade do cidadão brasileiro de baixa renda e semianalfabeto em se sentir representado pelo paradigma biomédico.

Severino [nome fictício] durante a escuta de programa, que noticiava a descrição do autoexame de mama proposto por um mastologista, interrompeu a escuta e contou que se um lactente "arrotar" no mamilo da mulher enquanto esta estiver amamentando, essa mulher vai ter caroço na mesma mama "arrotada". Diz ele que já viu isso acontecendo. Ele ainda explicou que "aquele líquido que vem, caso a criança arrote, volta para dentro do peito e cria um caroço" (Diário de campo).

Severino tenta explicar que "é a mesma coisa se um cara estiver fazendo sexo com uma senho- ra e se ela der um vento na hora é arriscado o cara passar mal". Quando lhe pergunto o porquê, ele responde: "porque deve entrar ar dentro do canal, né?” e complementa após uma pausa "eu sou uma pessoa que não tem estudo nem nada, mas tem essa prática” (Diário de campo).

Essas vivências da "prática" de Severino, por mais distantes do ponto de vista biomédico que possam parecer, produzem fortes representações de sentido, pois estão inseridas no seu contexto de concepção de mundo e constituindo a sua crença.

Loyola $^{21}$ identificou que "as pessoas idosas não só 'ensinam', como tendem, obviamente, a ser mais apegadas às práticas médicas populares e a encarar a medicina oficial com maior desconfiança”.

Essa autora também admite a importância do rádio e da televisão na formação da linguagem sobre os processos de adoecimento. "Frequentemente médicos assessoram os responsáveis pelos programas de saúde, isso quando não participam diretamente"21.

O médico frequentemente ao utilizar a mídia não contribui apenas na formação da linguagem do processo de adoecimento, mas também muitas vezes acaba reproduzindo o discurso medicalizante, difundindo a cultura medicalizante que, para Tesser $^{20}$, desvaloriza o saber popular, desqualificando-o por ser estranho e desviante da racionalidade biomédica. Esse mesmo autor analisa que, perante uma divulgação massiva medicalizante pela mídia, associada a todo um conjunto de insalubridades que sofre o cidadão de baixa renda, resta-lhe a opção de procurar os serviços de saúde independente se sua queixa será aliviada pela biomedicina.

Essa necessidade de alívio de angústias e de diminuição da insegurança por parte dos sujeitos, de acordo com Camargo $\mathrm{Jr}^{22}$, é apreendida na lógica do mercado como necessidade de consumo e rapidamente incorporada pela grande mídia, a qual se utiliza do rótulo de científico para legitimar o discurso medicalizante e persuadir o público consumidor.

A Rádio Comunidade através da divulgação desse tipo de informação contribui no sentido de esclarecer alguns abusos da medicalização, porém carece de um espaço maior no programa para melhor abordar a questão. Em contrapartida, esbarra muitas vezes num problema crucial percebido no estudo de campo: a dificuldade em aumentar a participação comunitária na rádio. 
Comunidade e comunicação na saúde: desafios na construção de estratégias de participação

Diferente das mídias comerciais que visam a abrangência de um maior número de pessoas, a mídia comunitária tem como característica ser territorializada, atingindo apenas uma parte específica da população. Isso faz com que a programação seja desenhada a partir das necessidades e interesses da população abrangida pela rádio.

Entretanto, em tempos de ampliação das fronteiras comunicativas, Malerba ${ }^{19}$ questiona essa necessidade de se configurar comunidade como um espaço demarcado territorialmente e analisa um conceito ampliado de comunidade, graças às novas tecnologias de informação e comunicação, que facilitam as identificações políticas e sociais entre os grupos sem necessariamente estarem juntos territorialmente.

Apesar de teoricamente uma rádio comunitária ser um espaço de representatividade popular que se propõe acolher todas as multiplicidades socioculturais existentes numa região, a população muitas vezes desconhece as funções de uma rádio comunitária. Um dos entrevistados, conselheiro de saúde destaca:

Esse [a Rádio Comunidade] é o canal de comunicação do povo, mas ele [o povo] não faz uso. $O$ povo brasileiro tem a cultura de não construir seu passado, seu presente e ficar esperando que o futuro aconteça na mão de alguém. [...] o futuro acontece na mão da própria população. A população não se toca disso, pelo próprio desconhecimento do seu direito. A rádio comunitária é importantíssima como canal de comunicação, principalmente na população de baixa renda. Mas as pessoas não têm a coragem, nem o hábito de irem à Rádio. Nem criticar, nem elogiar. Eles acham que aquilo lá é uma rádio privada, de difícil acesso (Conselheiro de saúde 1).

Para este entrevistado, o problema está centrado na falta de identificação por parte do povo em reconhecer a rádio comunitária como legítima representante popular. Não é uma questão de que o povo não saiba como funciona, e não entenda a serventia de uma rádio, mas sim, segundo ele, simplesmente o povo não prioriza e não participa.

De acordo com um ex-gestor de saúde de Friburgo, no âmbito da política partidária, a prioridade pelas mídias comunitárias não só está mais acentuada, como também, representa uma forte arena de disputa e barganha. Ele relata a importância de uma rádio para um vereador de oposição.
João [nome fictício] utilizou de forma muito importante, durante o período que fiquei lá, "o instrumento da rádio para fazer denúncias contra o governo". Tem uma base de apoio importante na comunidade. Explicita mazelas, embora sendo aquele jornalismo sensacionalista em que mostra o sangue, mostra o cara arrebentado, de cadeira de rodas, com muletas etc. [...] Pra esse cara era interessante fazer oposição, pois "era o único a ter instrumento de comunicação independente do governo na cidade. Em função disso se elegeu”. E como tendo a inferir que ele tem pretensões maiores no governo de lá, vai continuar utilizando seus instrumentos de comunicação de oposição, porque, com isso, ele tem um espaço diferenciado de negociação e de voto (Profissional de Saúde 1).

A fala de um conselheiro de saúde também explicita a instrumentalização da Rádio pelos políticos e gestores públicos:

Em vez de se gastar dinheiro aqui em Friburgo com mídia paga, "nós [o governo] deveríamos usar a rádio comunitária", porque atingiríamos exatamente o usuário do SUS. [...] Então os gestores deveriam utilizar a rádio comunitária para esclarecer a população: quais são os postos que estão fazendo vacinação, aonde a pessoa poderia ir para fazer um curativo. O desconhecimento da população é quando as pessoas não sabem para onde se direcionar. E aí você vê o caos instalado. "A rádio comunitária serviria como um veículo de comunicação para o governo". Mas como você já sabe é mais fácil gastar com mídia paga do que utilizar a rádio comunitária (Conselheiro de saúde 2).

Nesse caso, há uma dificuldade de compreensão sobre a diferença entre uma mídia comunitária e uma mídia estatal. O conselheiro até denuncia o gasto excessivo na mídia comercial, entretanto propõe que para se diminuir os gastos, e para se atingir "exatamente o usuário do SUS", a solução seria "usar a rádio comunitária". Como se não houvesse a necessidade de se negociar com a comunidade e com o conselho da rádio. Interessante frisar que o conselheiro entrevistado já participou do conselho e de programas da Rádio Comunidade.

Devido a essas e outras dificuldades, a capacidade de se construir estratégias de participação dentro da comunidade no campo da comunicação comunitária se coloca como um desafio, que apenas pode ser superado no exercício cotidiano de uma cidadania ativa, emancipadora, onde os sujeitos se sintam fortalecidos politicamente no cenário de um espaço público em busca dos interesses comunitários. 


\section{Considerações finais}

É importante deixar claro que teoricamente as rádios comunitárias representam a sociedade, mais especificamente a comunidade local. Sendo assim deve servir como mediadora não só entre a comunidade e a gestão pública, mas também entre os segmentos da sociedade civil, uma das principais funções de uma rádio comunitária. No entanto, devido às restrições jurídicas, técnicas e econômicas, aliadas à cultura política brasileira, muitas rádios comunitárias funcionam como rádios comerciais disfarçadas. A experiência em Nova Friburgo parece ser diferente em relação ao que ocorre no Brasil.

Analisamos que a comunicação comunitária e a saúde possam se encontrar tanto na produção de saberes, quanto no cotidiano dos serviços. A noção de potência e de campo de disputa da comunicação comunitária, através de suas mídias (rádio, televisão, jornal, fanzine, grafitagem etc), pode ser trabalhada e articulada pelas instâncias de comunicação da gestão em saúde.

No que se refere à assistência, a atenção primária parece ser o nível de melhores possibilidades desse encontro. Dentro da comunidade, pró- ximo às instituições como associação de moradores, igrejas, escolas, centros culturais, as equipes de saúde da família já convivem, e algumas já dialogam com as produções midiáticas locais.

Por fim, vimos que o campo da saúde tem muito ainda a dialogar com as mídias comunitárias, incluindo as rádios. Em alguns momentos se carece de um olhar mais atento ao território para mapear essas mídias, em outros, encontra-se uma desconfiança por parte da saúde coletiva em considerar esses espaços potencialmente eficazes para se trabalhar questões de saúde.

Independente da natureza da aproximação que possa acontecer entre a saúde e a rádio comunitária, são necessárias habilidades políticas e análise crítica de ambos os lados. Da saúde, o cuidado para não verticalizar conhecimentos, normas e práticas. Da rádio, a atenção para não reproduzir discursos hegemônicos sem uma análise crítica por parte dos representantes da comunidade.

Ao se tomar esses cuidados, o espaço da saúde e da comunicação tende a se tornar mais dialógico, nem sempre assumindo consensos, nem sempre produzindo um espaço harmônico, porém garantindo um espaço plural potencialmente democrático.

\section{Colaboradores}

A Oliveira Neto conduziu a investigação e redigiu $\mathrm{o}$ artigo. R Pinheiro orientou a pesquisa, fazendo a revisão final do texto. 


\section{Referências}

1. Cogo DM. No ar... uma rádio popular (o uso dos alto-falantes como emissora popular no Brasil) [dissertação]. São Paulo: Universidade de São Paulo; 1994.

2. Fernandéz AJP. Democratização do ar como exercício de cidadania [dissertação]. São Paulo: Universidade de São Paulo; 1998.

3. Costa OF. Rádio e política. Londrina: Eduel; 2005.

4. Cassol DB. A democratização da comunicação no Brasil: anotações teóricas e história do movimento [monografia]. Porto Alegre: Universidade Federal do Rio Grande do Sul; 2003.

5. Leal SAG. Rádio comunitária, espaço público e democracia: estudos de casos na França e no Brasil [doutorado]. Brasília: Universidade de Brasília; 2007.

6. Brasil. Lei no 9.612, de 19 de fevereiro de 1998. Institui o Serviço de Radiodifusão Comunitária e dá outras providências. Diário Oficial da União 1998; 19 fev.

7. Görgem J, coordenador. Donos da mídia.com. [acessado 2008 out 19]. Disponível em: http://donos damidia.com.br/levantamento/politicos

8. Paiva R. Para reinterpretar a comunicação comunitária. In: Paiva R, organizador. O retorno da comunidade: os novos caminhos do social. Rio de Janeiro: Mauad X; 2007. p.133-148.

9. Araújo IS, Cardoso J. Comunicação e saúde. Rio de Janeiro: Fiocruz; 2007.

10. Cardoso JM. Comunicação e Saúde: notas sobre a trajetória histórica e tendências atuais. Saúde em Foco 2004; 23:17-32.

11. Oliveira Neto A. Comunicação comunitária e saúde: a possibilidade de sintonia em uma só estação rumo à democratização dos espaços da mídia e do SUS [dissertação]. Rio de Janeiro: Universidade do Estado do Rio de Janeiro; 2010.

12. Araújo IS, Cardoso J. Circulação Polifônica: comunicação e integralidade na saúde. In: Pinheiro R, Mattos RA, organizadores. Construção social da demanda: direito à saúde, trabalho em equipe, participação e espaços públicos. Rio de Janeiro: Cepesc, UERJ, Abrasco; 2005. p. 239-251.
13. Jacks NA. Pesquisa de recepção: investigadores, paradigmas, contribuições latino-americanas. Intercom - Rev Bras de Com 1993; 16(1):22-33.

14. Jacks NA; Escosteguy AC. Práticas de recepção midiática: impasses e desafios da pesquisa brasileira. In: Anais do XIII Encontro anual da Compós, São Bernardo do Campo (SP); 2004.

15. Grohmann RN. Os estudos de recepção nos últimos trinta anos: revisão e perspectivas. In: Anais XIV Congresso de Ciências da Comunicação na Região Sudeste (Intercom); 2009; Rio de Janeiro; 2009.

16. Minayo MCS. O desafio do conhecimento: pesquisa qualitativa em saúde. São Paulo: Hucitec; 2007.

17. Gallo PR, Espírito Santo SKAM. A percepção de gestores de saúde sobre a rádio comunitária como instância mediadora para o exercício do controle social do SUS. Saúde em Debate 2009; 33(82):240-251.

18. Peruzzo CMK. Rádio comunitária, educomunicação e desenvolvimento. In: Paiva R, organizadora. $O$ retorno da comunidade: os novos caminhos do social. Rio de Janeiro: Mauad X; 2007. p. 69-94.

19. Malerba JPC. Rádios comunitárias: ampliando o poder de ação [monografia]. Rio de Janeiro: Universidade Federal do Rio de Janeiro; 2006.

20. Tesser CD. Medicalização social (I): o excessivo sucesso do epistemicídio moderno na saúde. Interface - Comun Saúde Educ 2006; 10(19):61-76.

21. Loyola MA. Médicos e curandeiros: conflito social e saúde. São Paulo: Difel; 1984.

22. Camargo Júnior KR. Public health and the knowledge industry. Rev de Saude Publica 2009; 43(6):10781083.

Artigo apresentado em 10/07/2012

Aprovado em 18/09/2012

Versão final aprovada em 15/04/2011 